\author{
Melis ÇERÇiOĞLU1 \\ Recep Serdar KARA² \\ Bülent OKUR²
}

1 Dumlupınar Üniversitesi, Simav Meslek yüksek Okulu, 43500,Simav Kütahya / Türkiye

${ }^{2}$ Ege Üniversitesi, Ziraat Fakültesi, Toprak Bilimi ve Bitki Besleme Bölümü, 35100 İzmir / Türkiye

sorumlu yazar: melis.cercioglu@dpu.edu.tr

Anahtar Sözcükler:

Sera, Simav yöresi, sulama suyu

özellikleri, toprak özellikleri

Key Words:

Greenhouse, Simav region, irrigation water characteristics, soil characteristics

\section{Kütahya -Simav Yöresi Sera Topraklarının ve Sulama Suyu Özelliklerinin Araştırılması Üzerine Bir Ön Çalışma}

\author{
Pre Investigation on Research of Greenhouse Soil \\ and Irrigation Water Characteristics of Kutahya-Simav Region
}

Alınış (Received): 20.06.2016 Kabul tarihi (Accepted): 18.10.2016

\section{ÖZET}

D u çalışma Kütahya'nın Simav ilçesindeki seralardan alınan su ve toprak örneklerinin kalite özelliklerinin araştırılması amacıyla yapılmıştır. Bu amaçla Simav yöresindeki 20 farklı seradan toprak ve su örneği alınmıştır. Toprak örnekleri, seralarda başlayan bitkisel üretim öncesi ve sonrası olmak üzere iki kez; su örnekleri ise üretim başlangıcı, ortası ve sonunda olmak üzere üç defa alınmıştır. Toprak örneklerinde bünye, $\mathrm{pH}$, elektriksel iletkenlik, organik madde, makro ve mikro elementler ile ağır metal analizleri yapılmıştır. Su örneklerinin ise kimyasal özellikleri incelenmiştir. Analiz sonuçlarına göre toprak örneklerinin büyük bir kısmının hafif bünyeli, hafif asit, tuzsuz, az düzeyde organik madde içerdiği bulunmuştur. Toprakların toplam azot (N) kapsamı bakımından zengin; alınabilir fosfor (P), potasyum (K), magnezyum $(\mathrm{Mg})$ ve bakır $(\mathrm{Cu})$ bakımından ise fazla düzeyde olduğu gözlenmiştir. Alınabilir sodyum ( $\mathrm{Na}$ ) ve kalsiyum (Ca) içeriği bakımından orta; demir ( $\mathrm{Fe}$ ) ve mangan (Mn) bakımından yeterli; çinko (Zn) bakımından üretim öncesi düşük, üretim sonrası ise yüksek olarak belirlenmiştir. Ayrıca toprakların ağır metal konsantrasyonlarının sınır değerlerini aşmadığı gözlenmiştir. Su örneklerinin kimyasal özelliklerinin incelenmesi sonucunda ise sulama suyu olarak kullanımında herhangi bir sakınca olmadığı ve ABD Tuzluluk Laboratuvar Sistemi'ne göre sınıflandırıldığında C2S1 sınıfına girerek kullanılabilir nitelikte olduğu görülmüştür.

\section{ABSTRACT}

$\mathbf{T}$ he study was carried out to investigate some quality properties of greenhouse soils and irrigation waters in the Simav region of Kutahya. For this aim, soil and water samples were taken from $\mathbf{2 0}$ different greenhouses. Soil samples were taken two times before and after planting period; while water samples were taken three times before, middle and after planting period. Texture, pH, electrical conductivity, organic matter and the concentrations of macro and micro elements and heavy metals in the soil samples were analyzed. Also, the chemical properties of irrigation water samples were investigated. According to the results; the majority of soils were found light textured, slightly acidic, low salinity and they contained low amount of organic matter. The total nitrogen (N) amounts of soil samples were rich level; available phosphorus (P), potassium (K), magnesium (Mg) and copper (Cu) amounts were high level. Extractable sodium ( $\mathrm{Na}$ ) and available calcium (Ca) contents were moderate level; available iron (Fe) and manganese (Mn) were efficient level; zinc amounts were low level before planting period and high level after planting period. Moreover, it was observed that heavy metal concentrations of soils did not exceed limit values. When the analyses of chemical properties of water samples, it was observed that water was suitable for irrigation and classified C2S1 according to U.S. Salinity Laboratory System classification. 


\section{GíRiş}

Sera topraklarındaki bitki besin maddelerinin bitkiler tarafından fazla miktarda alınması, aşırı veya yetersiz gübreleme, aşırı sulama gibi faaliyetler sonucunda toprak özellikleri zaman içerisinde bozulmakta ve bu durum bitkiye olumsuz etki etmektedir. Bu nedenle; tarımsal üretimin yoğun olduğu seralar gibi yerlerde uygulanacak tarımsal işlemler öncesi toprak ve sulama suyu özellikleri iyi bilinmelidir. Toprak verimliliğinin sürdürülebilmesinde bitkilerce kaldırılan besin maddelerinin toprağa ilave edilmesi diğer bir deyişle gübreleme yapılması önemli konulardan birisi olarak karşımıza çıkmakla birlikte sulama suyunun kalitesi de önemli bir faktördür. Üretimde artışın sağlanması genellikle entansif tarım tekniklerinin kullanılması veya kapalı sera koşullarında kontrollü yetiştiricilik ile mümkün olabilmektedir. Simav gibi jeotermal suların yoğun olduğu yörelerde, sulama sularına termal suların karışma olasılığı ve beraberinde bazı ağır metaller ve bor elementinin sular ile toprak ve bitkilere taşınması mümkün olabilmektedir. Gerek kapalı alan gerekse açık alanlardaki bitkisel üretim öncesi toprakların fizikokimyasal özellikleri ile sulama sularının özelliklerinin bilinmesi zorunludur. Toprak analizleri ile toprakta var olan besin maddelerinin bitkilere yarayışlı konsantrasyonları belirlenerek toprakların bitkilere besin sağlama güçleri ortaya çıkarılmakta ve bulunan yetersizlikler gübreleme ile giderilebilmektedir. Ancak yetiştiricilik aşamalarında yapılan yanlış uygulamalar, uygulayıcılara dolaylı yollardan ulaşmakta ve oluşan olumsuzluklar zaman içerisinde kendini göstermektedir. Gelişmiş ülkelerde nüfus artışı $\% 0.5$ düzeyinde iken gelişmekte olan ülkelerde bu oran \% 2.5'e kadar çıkabilmektedir (Çamurcu, 2005). Olanakların daha sınırlı olduğu gelişmekte olan ülkelerde, artan nüfusun ihtiyaçlarını karşılamak amacıyla kimi zaman güvenlik ve çevre kirliliği gibi etkileri uzun süre sonra ortaya çıkabilecek konular daha az dikkate alınmakta ve bunun sonucu olarak tarımsal alanlarda kontrolsüz gübre ve ilaç kullanımı gündeme gelebilmektedir (Atılgan ve ark., 2007). Seralarda, özellikle yetiştiriciliğin yoğun olduğu sezon boyunca kimyasal gübreler çok yüksek miktarlarda kullanılmakta ve bu nedenle su kaynakları özellikle de termal bölgelerdeki sulama suları tehlikeli boyutlarda kirlenebilmektedir (Kaplan ve ark., 1999). $\mathrm{Bu}$ durum bazen üreticinin de dikkatinden kaçabilmekte ve uzun vadede topraklarda kirlenme kendini göstermektedir.

Bu çalışma ile Kütahya ilinin Simav yöresindeki seralarda yoğun bir şekilde üretimi yapılan domates, hıyar, patlıcan, kabak, biber vb. sebzelerin yetiştiği toprakların ve sulama sularının kalite özelliklerini ortaya koymak ve sonuçlarına göre gerekirse şimdiden önlemleri almak amacıyla gerçekleştirilmiştir.

\section{MATERYAL ve YÖNTEM}

\section{Materyal}

Çalışma kapsamında, domates ve hıyar yetiştiriciliği yapılan, toplam yüzölçümü ile 46.7 dekar alanı temsil eden Simav yöresindeki 20 ayrı seradan toprak ve su örneği alınmıştır. Toprak örnekleri, seralarda başlayan bitkisel üretim öncesi (7 Temmuz 2014) ve sonrası (13 Ekim 2014) olmak üzere iki kez; su örnekleri ise üretim başlangıcı (7 Temmuz 2014), ortası (8 Ağustos 2014) ve sonunda (13 Ekim 2014) olmak üzere üç kez alınmıştır. 1 ve 20 numaralı seraların tarımsal üretimde kullandıkları suyun aynı olması sebebiyle, su analizleri 19 örnek üzerinden yürütülmüştür. Toprak ve su örneklerinin alındığı seralara ait bazı bilgiler Çizelge 1'de verilmiştir.

Çizelge 1. Toprak ve su örneklerinin alındığı seraların genel özellikleri (Simav 4 Eylül Tarımsal Kalkınma Kooperatifi, 2014)

Table 1. General characteristics of soil and water samples taken from greenhouses (Simav 4 Eylül Tarımsal Kalkınma Kooperatifi, 2014)

\begin{tabular}{|c|c|c|c|c|c|c|}
\hline Sera No & Üretici & Su Kaynağı & Su Derinliği & Sera Büyüklüğü & Yetiştirilen Ürün & Sulama Sıklığı \\
\hline 1 & Ziya Gündem & Kendi Suyu & $24 \mathrm{~m}$ & $2800 \mathrm{~m}^{2}$ & Domates & 2 günde 1 \\
\hline 2 & Osman Keldi & Kooperatif & & $3000 \mathrm{~m}^{2}$ & Domates & 2 günde 1 \\
\hline 3 & Osman Keldi & Belediye & & $2000 \mathrm{~m}^{2}$ & Domates & 2 günde 1 \\
\hline 4 & İbrahim Başdemir & Kendi Suyu & & $2800 \mathrm{~m}^{2}$ & Hıyar & 2 günde 1 \\
\hline 5 & Yusuf Erdoğan & Kendi Suyu & $30-35 \mathrm{~m}$ & $1500 \mathrm{~m}^{2}$ & Domates & Her gün \\
\hline 6 & Erdem Kahraman & Kendi Suyu & $17 \mathrm{~m}$ & $2000 \mathrm{~m}^{2}$ & Domates & Her gün \\
\hline 7 & Murat Durukan & Belediye & & $2000 \mathrm{~m}^{2}$ & Hıyar & Haftada 2-3 kez \\
\hline 8 & Yunus Altınışık & Kooperatif & & $1000 \mathrm{~m}^{2}$ & Domates & Her gün \\
\hline 9 & Osman Çııbık & Kooperatif & & $2000 \mathrm{~m}^{2}$ & Hıyar & 2 günde 1 \\
\hline 10 & Halil Kurt & Kooperatif & & $2000 \mathrm{~m}^{2}$ & Domates & 2 günde 1 \\
\hline 11 & Eşref Çimen & Kooperatif & & $3500 \mathrm{~m}^{2}$ & Domates & 2 günde 1 \\
\hline 12 & Şener Göker & Kooperatif & & $1920 \mathrm{~m}^{2}$ & Domates & 2 günde 1 \\
\hline 13 & Mehmet Bulut & Kendi Suyu & & $2000 \mathrm{~m}^{2}$ & Domates & 2 günde 1 \\
\hline 14 & Hüseyin Öztürk & Kendi Suyu & $7 \mathrm{~m}$ & $4000 \mathrm{~m}^{2}$ & Domates & 2 günde 1 \\
\hline 15 & Necmettin Aslan & Kooperatif & & $2700 \mathrm{~m}^{2}$ & Domates & Her gün \\
\hline 16 & Kamil Key & Kooperatif & & $3000 \mathrm{~m}^{2}$ & Domates & Her gün \\
\hline 17 & Ali Key & Kooperatif & & $2000 \mathrm{~m}^{2}$ & Domates & Her gün \\
\hline 18 & Mehmet Baştuğ & Kooperatif & & $1200 \mathrm{~m}^{2}$ & Domates & 2-3 günde 1 \\
\hline 19 & Ahmet Keldi & Kooperatif & & $1500 \mathrm{~m}^{2}$ & Domates & 2 günde 1 \\
\hline 20 & Ziya Gündem & Kendi Suyu & $24 m$ & $3800 \mathrm{~m}^{2}$ & Domates & 2 günde 1 \\
\hline
\end{tabular}




\section{Yöntem}

Laboratuvara getirilen toprak örnekleri, hava kurusu hale geldikten sonra $2 \mathrm{~mm}$ çapındaki elekten elenip toprak analizlerine hazır hale getirilmiştir. Toprak örneklerinin pH (Jackson, 1958) ve elektriksel iletkenlik değerleri (U.S. Salinity Lab. Staff, 1954), sature hale getirilmiş toprakta pH-metre ve EC-metre ile gerçekleştirilmiş̧ir. Kireç analizi volümetrik (Schlichting and Blume, 1966); organik madde, modifiye edilmiş Walkley Black (Nelson and Sommer, 1982); bünye, hidrometre (Black, 1965); toplam azot (N), modifiye edilmiş Kjeldahl (Bremner, 1965); alınabilir fosfor (P), Olsen (Olsen et al., 1954); alınabilir potasyum (K), sodyum $(\mathrm{Na})$, kalsiyum $(\mathrm{Ca})$ ve magnezyum $(\mathrm{Mg}), 1 \mathrm{~N}$ $\mathrm{NH}_{4} \mathrm{OAC}$ yöntemleri (Pratt, 1965) ile belirlenmiştir. Toprak örneklerinin alınabilir demir (Fe), bakır (Cu), mangan $(M n)$ ve çinko $(\mathrm{Zn})$ içerikleri DTPA yöntemi ile belirlenmiştir (Lindsay and Norvell, 1978). Örneklerin toplam ağır metal içerikleri ise kral suyunda (1:3 $\mathrm{HCl}: \mathrm{HNO}_{3}$ ) yas yakılmaları sonrası atomik absorbsiyon spektrometrede belirlenmiștir (Kick et al., 1980). Su örneklerinin $\mathrm{pH}$ ve elektriksel iletkenlik değerleri; anyon $\left(\mathrm{Cl}, \mathrm{HCO}_{3}{ }^{-}, \mathrm{SO}_{4}^{-2}\right)$ ve katyon $\left(\mathrm{Ca}^{+2}+\mathrm{Mg}^{+2}, \mathrm{Na}^{+}, \mathrm{K}^{+}\right)$ içeriklerine yönelik analizler Motsara and Roy (2008)'a göre gerçekleştirilmiştir. Örneklerin bor (B) analizleri ise Azomethin-H yöntemiyle belirlenmiştir (Bingham, 1982).

\section{ARAŞTIRMA BULGULARI ve TARTIŞMA \\ Bünye, $\mathrm{pH}$, elektriksel iletkenlik ve organik madde}

Simav yöresinde belirlenen toplam 20 adet seradan alınan toprak örneklerine ait fiziksel ve kimyasal analiz sonuçları Çizelge 2'de verilmiştir. Genel olarak kumlu tın bünyeye sahip olan topraklar ortalama olarak $\% 71.87$ kum, \% 19.94 mil ve \% 8.19 kil içermektedirler. Toprakların ortalama kireç içeriği ise \%1.76 ile Evliya (1964)'ya göre \%1-5 arasında az kireçli olarak belirlenmiştir. Toprak örneklerinin kimyasal özelliklerinden $\mathrm{pH}$ ve elektriksel iletkenlik değerleri üretim öncesi sırasıyla; 4.46-7.31 ve $351-3300 \mu \mathrm{S} \mathrm{cm}^{-1}$, üretim sonrası ise sırasıyla; 5.53-7.63 ve $514-3550 \mu \mathrm{S} \mathrm{cm}^{-1}$ aralığında değişmiştir (Çizelge 2).

Çizelge 2. Sera topraklarının bazı fiziksel ve kimyasal özellikleri

Table 2. Some physical and chemical properties of greenhouse soils

\begin{tabular}{|c|c|c|c|c|c|c|c|c|c|c|c|}
\hline \multirow[b]{2}{*}{ Sera No } & \multicolumn{8}{|c|}{ Üretim Sezonu Öncesi } & \multicolumn{3}{|c|}{ Üretim Sezonu Sonrası } \\
\hline & $\begin{array}{c}\text { Kum } \\
\text { (\%) }\end{array}$ & $\begin{array}{l}\text { Mil } \\
\text { (\%) }\end{array}$ & $\begin{array}{l}\text { Kil } \\
(\%)\end{array}$ & $\begin{array}{l}\text { Bünye } \\
\text { sınıfı }\end{array}$ & pH & $\begin{array}{c}\text { EC } \\
\left(\mu \mathrm{Scm}^{-1}\right)\end{array}$ & $\begin{array}{c}\text { Org.Madde } \\
(\%)\end{array}$ & $\begin{array}{l}\text { Kireç } \\
(\%)\end{array}$ & pH & $\begin{array}{c}\text { EC } \\
\left(\mu \mathrm{S} \mathrm{cm}^{-1}\right)\end{array}$ & $\begin{array}{c}\text { Org.Madde } \\
\text { (\%) }\end{array}$ \\
\hline 1 & 68.12 & 18.64 & 13.24 & Kumlu Tın & 6.27 & 2590 & 2.00 & 1.44 & 7.3 & 1805 & 2.14 \\
\hline 2 & 77.12 & 16.64 & 6.24 & Tınlı Kum & 6.29 & 2100 & 4.24 & 1.37 & 7.2 & 1342 & 6.12 \\
\hline 3 & 75.12 & 17.64 & 7.24 & Kumlu Tın & 6.12 & 1020 & 3.04 & 1.14 & 7.29 & 716 & 3.23 \\
\hline 4 & 67.12 & 21.64 & 11.24 & Kumlu Tın & 7.31 & 1190 & 2.99 & 5.09 & 7.63 & 1540 & 1.88 \\
\hline 5 & 83.12 & 13.64 & 3.24 & Tınlı Kum & 5.38 & 751 & 1.11 & 1.06 & 6.7 & 974 & 1.49 \\
\hline 6 & 81.12 & 15.64 & 3.24 & Tınlı Kum & 4.46 & 954 & 1.73 & 0.99 & 6.11 & 1315 & 0.77 \\
\hline 7 & 65.12 & 22.64 & 12.24 & Kumlu Tın & 7.3 & 761 & 4.55 & 4.63 & 7.46 & 1005 & 3.46 \\
\hline 8 & 77.12 & 15.64 & 7.24 & Kumlu Tın & 6.46 & 855 & 3.72 & 1.67 & 6.25 & 3550 & 3.22 \\
\hline 9 & 77.12 & 15.64 & 7.24 & Kumlu Tın & 6.64 & 2000 & 2.55 & 1.52 & 6.17 & 2090 & 2.49 \\
\hline 10 & 72.12 & 18.64 & 9.24 & Kumlu Tın & 5.82 & 1684 & 1.92 & 1.22 & 6.33 & 760 & 0.84 \\
\hline 11 & 73.12 & 16.64 & 10.24 & Kumlu Tın & 7.05 & 928 & 1.92 & 3.19 & 7.35 & 840 & 1.64 \\
\hline 12 & 71.12 & 20.64 & 8.24 & Kumlu Tın & 6.23 & 826 & 2.11 & 0.99 & 5.6 & 971 & 0.77 \\
\hline 13 & 69.12 & 21.64 & 9.24 & Kumlu Tın & 6.21 & 2450 & 1.26 & 0.99 & 6.52 & 1108 & 1.56 \\
\hline 14 & 85.12 & 3.64 & 11.24 & Tınlı Kum & 5.15 & 1184 & 1.79 & 0.84 & 5.65 & 1361 & 1.94 \\
\hline 15 & 82.12 & 12.64 & 5.24 & Tınlı Kum & 6.86 & 772 & 1.44 & 1.37 & 6.55 & 514 & 1.03 \\
\hline 16 & 70.12 & 24.64 & 5.24 & Kumlu Tın & 6,46 & 3300 & 2.37 & 1.37 & 6.18 & 895 & 0.94 \\
\hline 17 & 63.12 & 29.64 & 7.24 & Kumlu Tın & 7.05 & 1608 & 3.69 & 1.44 & 7.02 & 1426 & 2.65 \\
\hline 18 & 76.12 & 15.64 & 8.24 & Kumlu Tın & 6.31 & 2390 & 2.53 & 2.74 & 6.89 & 2620 & 1.47 \\
\hline 19 & 71.12 & 19.64 & 9.24 & Kumlu Tın & 7.02 & 514 & 1.96 & 1.14 & 6.66 & 753 & 1.90 \\
\hline 20 & 33.12 & 57.64 & 9.24 & Milli Tın & 6.07 & 351 & 2.51 & 0.99 & 5.53 & 1476 & 1.74 \\
\hline Ort. & 71.87 & 19.94 & 8.19 & Kumlu Tın & 6.32 & 1411 & 2.47 & 1.76 & 6.62 & 1353 & 2.06 \\
\hline V.K. & 15.22 & 51.60 & 33.45 & - & 11.48 & 57.40 & 39.00 & 68.75 & 9.68 & 53.62 & 61.00 \\
\hline S.S. & 10.94 & 10.29 & 2.74 & - & 0.72 & 810.22 & 0.96 & 1.21 & 0.64 & 725.53 & 1.30 \\
\hline Min. & 33.12 & 3.64 & 3.24 & - & 4.46 & 351 & 1.11 & 0.84 & 5.53 & 514 & 0.77 \\
\hline Mak. & 85.12 & 57.64 & 13.24 & - & 7.31 & 3300 & 4.55 & 5.09 & 7.63 & 3550 & 6.12 \\
\hline
\end{tabular}

Ort: Ortalama; V.K.: Varyasyon Katsayısı; S.S.: Standart Sapma; Min.: Minimum; Mak.: Maksimum

Toprakların üretim sezonu öncesi $\mathrm{pH}$ değerleri USDA (1998)'ya göre sınıflandırıldığında; \% 45'inin hafif asit (pH: 6.1-6.5), \% 30'unun nötr (pH: 6.6-7.3), \%10'unun kuvvetli asit (pH: 5.1-5.5), \% 5'inin çok kuvvetli asit (pH: 4.5-5.0), \%5'inin orta asit (pH: 5.6-6.0) ve \%5'inin hafif alkali ( $\mathrm{pH}: 7.4-7.8$ ) reaksiyon gösterdiği belirlenmiştir. Üretim sezonu sonrası bu dağılım, toprakların \%45'inin nötr, \%20'sinin hafif alkali, $\% 20$ sinin hafif asit ve \%15'inin orta asit reaksiyon şekilde değişmiştir. Böylece toprak örneklerinin $\mathrm{pH}$ değerleri \% 4.40 ile \% 24 arasında bir değişim göstermiş olup en çok değişim, düşük pH değerlerinin artışı şeklinde gerçekleşmiştir. Vejetasyon dönemi boyunca yapılan gübreleme faaliyetleri ile toprakların $\mathrm{pH}$ 
değerlerinde yükselme gerçekleşmiştir. Çoğunlukla domates yetiştiriciliği yapılan Simav yöresi sera topraklarının ortalama pH değeri (6.47), Ata (2015)'ya göre domates bitkisinin gelişebilmesi için gereken $\mathrm{pH}$ sınır değerleri (5-7) arasında bulunmaktadır. Bu bilgiler ışığı altında değerlendirme yapıldığında bu çalışmada Simav yöresi sera toprak reaksiyonlarının sebze yetiştiriciliği açısından uygun olduğu görülmektedir. Toprak elektriksel iletkenlik değerlerini incelediğimizde düşük elektriksel iletkenlik gösteren topraklar üretim sonunda daha fazla tuzlanmış ve bu oran $\% 7.50$ ile $\% 46$ ile arasında değişim göstermiştir. Üretim öncesi toprakların elektriksel iletkenlik değerleri USDA (2002)'ya göre sınıflandırıldığında, toprakların \% 70'inin tuzluluk göstermediği $\left(0-2000 \mu \mathrm{S} \mathrm{cm} \mathrm{cm}^{-1}\right), \% 30^{\prime}$ unun ise hafif tuzluluk gösterdiği belirlenmiştir $\left(2000-4000 \mu \mathrm{S} \mathrm{cm} \mathrm{cm}^{-1}\right)$. Üretim sonrası ise sera topraklarının \% 85'i tuzluluk göstermezken, \% 15'inin hafif tuzluluk gösterdiği belirlenmiştir. Bu veriler dikkate alındığında; 4-5-6-7-912-14-18-19 numaralı seralarda toprakların tuz içeriği üretim sonrasında az da olsa artarken, 8 ve 20 numaralı seralardaki toprakların tuz içeriği çok fazla olarak analiz edilmiştir. Bu durum büyük olasılıkla toprağa üreticiler tarafından ilave edilen yapay veya doğal gübrelerden kaynaklanmaktadır. Buna karşıık 1-2-3-11-15-17 numaralı sera topraklarının tuz içeriği üretim sonrası düşerken, 13 ve 16 numaralı sera topraklarında düşüş çok belirgin olmuştur. Bu azalma ise toprakların bol sulama suyu uygulanması sonucu yıkanması ile açıklanabilir. Akay ve Kaplan (1995) tarafında yapılan çalışmada hıyar ve domates yetiştirilen sera topraklarının tuz içeriklerinin dönemsel değişimi incelenmiş ve toprakların tuz içeriğinin yetiştirme dönemi boyunca arttığı belirlenmiştir. Tuz içeriğinin artmasının nedeni olarak da gübre uygulamaları gösterilmiştir. Sebzeler genel olarak tuza hassas bitkilerdir (Moltay et al., 1995). Domates, sulama suyunun ve toprağın tuzluluğunu sevmeyen, yüksek tuzluluktan zarar gören bir bitkidir (Çolakoğlu, 1985). Çoğunlukla domates yetiştiriciliği yapılan yörede, sera topraklarında tuzluluk yönünden bir sorun olmadığı belirlenmiştir.

Birinci ve ikinci toprak örneklerinin organik madde içerikleri sırasıyla; \%1.11-4.55 ve 0.77-6.12 aralığında değişim göstermiştir. Üretim öncesi toprakların $\% 60$ 'ının orta (\%2-5) ve \%40'ının az düzeyde (\%1-2) organik madde içerdiği belirlenmiştir. Üretim sonrası bu durum çeşitlenmiş ve toprakların $\% 45^{\prime}$ inin az, \% 30 'unun orta, \%20'sinin çok az ve \%10'unun fazla düzeyde (\%5-10) organik madde içerdiği analiz edilmiştir. Elde edilen sonuçlara göre sera topraklarının genel olarak organik madde içeriklerinin yetersiz olduğunu söylemek mümkündür.

\section{Makro besin elementleri ( $\mathrm{Na}, \mathrm{K}, \mathrm{Ca}, \mathrm{Mg}$ )}

Sera topraklarının üretim sezonu öncesi ve sonrası makro besin elementi içerikleri Çizelge 3'de verilmiştir.

Çizelge 3. Sera topraklarının alınabilir makro element içerikleri Table 3. Available macro nutrients of greenhouse soils

\begin{tabular}{|c|c|c|c|c|c|c|c|c|}
\hline \multirow{3}{*}{ Sera No } & \multicolumn{4}{|c|}{ Üretim Sezonu Öncesi } & \multicolumn{4}{|c|}{ Üretim Sezonu Sonrası } \\
\hline & $\mathrm{Na}$ & $\mathbf{K}$ & $\mathrm{Ca}$ & Mg & $\mathrm{Na}$ & $\mathbf{K}$ & $\mathrm{Ca}$ & $\mathbf{M g}$ \\
\hline & \multicolumn{4}{|c|}{$\left(\mathrm{mg} \mathrm{kg}^{-1}\right)$} & \multicolumn{4}{|c|}{$\left(\mathrm{mg} \mathrm{kg}^{-1}\right)$} \\
\hline 1 & 235 & 745 & 1382 & 355 & 158 & 624 & 2151 & 330 \\
\hline 2 & 203 & 867 & 1234 & 310 & 170 & 604 & 2469 & 307 \\
\hline 3 & 87 & 236 & 1283 & 238 & 125 & 217 & 1951 & 218 \\
\hline 4 & 110 & 323 & 2270 & 285 & 195 & 237 & 2867 & 275 \\
\hline 5 & 83 & 47 & 691 & 125 & 144 & 69 & 1613 & 155 \\
\hline 6 & 92 & 504 & 691 & 140 & 144 & 346 & 1115 & 150 \\
\hline 7 & 83 & 244 & 2122 & 323 & 89 & 297 & 2788 & 305 \\
\hline 8 & 97 & 386 & 1184 & 340 & 265 & 901 & 2071 & 324 \\
\hline 9 & 120 & 331 & 1135 & 329 & 146 & 574 & 1513 & 308 \\
\hline 10 & 101 & 244 & 987 & 280 & 91 & 138 & 1115 & 257 \\
\hline 11 & 120 & 299 & 2171 & 360 & 93 & 178 & 2111 & 342 \\
\hline 12 & 69 & 165 & 987 & 205 & 105 & 208 & 1115 & 219 \\
\hline 13 & 383 & 252 & 1678 & 366 & 170 & 217 & 1673 & 324 \\
\hline 14 & 184 & 141 & 888 & 258 & 152 & 208 & 1414 & 250 \\
\hline 15 & 92 & 130 & 592 & 187 & 60 & 89 & 1115 & 181 \\
\hline 16 & 406 & 1182 & 1135 & 421 & 177 & 346 & 956 & 403 \\
\hline 17 & 175 & 559 & 1777 & 403 & 152 & 594 & 2190 & 381 \\
\hline 18 & 277 & 563 & 2073 & 340 & 220 & 554 & 2748 & 314 \\
\hline 19 & 18 & 323 & 1530 & 233 & 93 & 138 & 1872 & 226 \\
\hline 20 & 323 & 867 & 1875 & 444 & 97 & 554 & 1155 & 411 \\
\hline Ort. & 162.9 & 420.8 & 1384 & 297.1 & 142.3 & 355.1 & 1800 & 284 \\
\hline V.K. & 66.8 & 70.3 & 38 & 29.9 & 35.1 & 64.3 & 34.2 & 26.7 \\
\hline S.S. & 109.2 & 296 & 526.7 & 88.9 & 50.1 & 228.6 & 616.5 & 284 \\
\hline Min. & 18 & 47 & 592 & 125 & 60 & 69 & 955 & 150 \\
\hline Mak. & 406 & 1182 & 2270 & 444 & 265 & 901 & 2867 & 411 \\
\hline
\end{tabular}

Ort: Ortalama; V.K.: Varyasyon Katsayısı; S.S.: Standart Sapma; Min.: Minimum; Mak.: Maksimum 
Üretim sezonu öncesi toprakların alınabilir sodyum içerikleri 18-406 $\mathrm{mg} \mathrm{kg}^{-1}$, üretim sezonu sonrası 60-265 $\mathrm{mg} \mathrm{kg}{ }^{-1}$ aralığında gözlenmiştir. Üretim öncesinde toprakların alınabilir sodyum içerikleri Pratt (1965)'a göre sınıflandıııldığında; \% 70'inin orta (68-230 mg kg $\left.{ }^{-1}\right)$, $\% 25^{\prime}$ inin çok yüksek (230-460 mg kg-1); \% 5'inin çok düşük $\left(<34 \mathrm{mg} \mathrm{kg}^{-1}\right)$ düzeyde alınabilir sodyum içerdiği analiz edilmiştir. Bu dağılım üretim sezonu sonrasında $\% 90$ orta, $\% 5$ çok yüksek ve $\% 5$ düşük seviyede alınabilir sodyum içeriği şeklinde gerçekleşmiştir. Bu da sera topraklarının alınabilir sodyum elementi bakımından şu an için herhangi bir tehlike yaratmadığını göstermektedir. Maltaş ve Kaplan (2015) örtüaltı güzlük domates bitkilerinin beslenme durumlarının belirlenmesi ile ilgili yaptıkları çalışmada topraklarının alınabilir sodyum içeriklerini $0.10-2.49$ me $100 \mathrm{~g}^{-1}$ arasında olduğunu ve Kacar (1962)'a göre sınıflandıııldığında sera topraklarının \%62.2'sinin orta düzeyde alınabilir sodyum içerdiği, \%12.6'sının da yüksek ve çok yüksek düzeyde alınabilir sodyum içerdiğini belirlemişlerdir.

Toprakların alınabilir potasyum içeriği ilk örneklemede $47-1182 \mathrm{mg} \mathrm{kg}^{-1}$; ikinci örnekleme sonucunda ise $69-$ $901 \mathrm{mg} \mathrm{kg}^{-1}$ arasında değişmiştir. Alınabilir potasyum değerleri Fawzi and El Fouly (1980)'e göre sınıflandırıldığında sınıflandırıldığında, ilk örneklemede toprakların \%35'inin çok yüksek (>400 mg kg-1), \%20' sinin yüksek (300-400 mg kg-1), \% 20'sinin yeterli (200$\left.300 \mathrm{mg} \mathrm{kg}^{-1}\right), \% 15^{\prime}$ inin yetersiz $\left(<150 \mathrm{mg} \mathrm{kg}^{-1}\right)$ ve $\% 5$ 'inin düşük seviyede alınabilir potasyum içerdiği belirlenmiştir. Bu dağılım üretim sonrası; $\% 35$ çok yüksek, \%30 yeterli, $\% 20$ yetersiz ve $\% 5$ düşük düzeyde alınabilir potasyum içeriği olarak bulunmuştur. Topraklarda potasyum elementi genelde üretim sonrası bir azalma eğilimi göstermiştir. Potasyum elementi bitkiler tarafından çok fazla miktarda kaldıılan bir makro besin maddesidir. Yedek besin maddelerinin depolanması, şeker ve nişastanın oluşumu ve taşınması, protein sentezi, soğuğa dayanıklılık vb. gibi birçok metabolik olaylarda faaliyet gösterir (Manga ve ark., 1995; Açıkgöz, 2001). Bazı sera topraklarında çok az da olsa (5-7-8-9-12-14 ve 17 no'lu seralarda) genel olarak hafif bir artış analiz edilmiştir. Bu durumun aşırı gübre uygulamalarından da kaynaklanmış olabileceği düşünülmektedir. Yapılan çeşitli araştırmalarda $\mathrm{da}$, toprakların alınabilir potasyum kapsamlarının gübreleme ile arttığı ve kimyasal özelliklerinin geliştiği belirtilmiştir (N'dayegamiye and Cote, 1989; Press et al., 1996; Shen et al., 1996; Çerçioğlu ve ark., 2010). Sera topraklarının alınabilir kalsiyum içerikleri üretim öncesi ve sonrası sırasıyla; $592-2270 \mathrm{mg} \mathrm{kg}^{-1}$ ve $955-2867 \mathrm{mg}$ $\mathrm{kg}^{-1}$ değerleri arasında değişmiştir. Üretim başında, toprakların \% 45'i düşük (714-1428 $\left.\mathrm{mg} \mathrm{kg}^{-1}\right), \% 30^{\prime} \mathrm{u}$ orta $\left(1428-2143 \mathrm{mg} \mathrm{kg}^{-1}\right), \%$ 15'i çok düşük $\left(<714 \mathrm{mg} \mathrm{kg}^{-1}\right)$ ve \%10'u yüksek (2143-2857 $\mathrm{mg} \mathrm{kg}^{-1}$ ) kalsiyum değerlerine sahipken; üretim sonunda bu dağılım \% 35 düşük, \% 35 orta, \%25 fazla ve \%5 çok fazla (>2857) şeklinde değişim göstermiştir (Pratt, 1965). Kalsiyum elementi genelde sera topraklarında artış göstermiştir. Bu artış miktarının da mutlaka izlenmesi gereklidir. Özellikle seralarda kalsiyum elementi bazı mikro elementlerin alınımını engelleyeceği için dikkatli olunmalıdır. Kalsiyum elementinin özellikle fosfor, potasyum, magnezyum ve mikro elementlerle interaksiyona girdiği yapılan birçok çalışma ile ortaya konulmuştur (Fageria, 2001). Toprakların alınabilir magnezyum içerikleri ise üretim öncesi ve sonrası sırasıyla; $125-444 \mathrm{mg} \mathrm{kg}^{-1}$ ve $150-411$ $\mathrm{mg} \mathrm{kg}^{-1}$ arasında değiştiği gözlenmiştir. Birinci örneklemede toprakların alınabilir magnezyum içerikleri Pratt (1965)'a göre sınıflandırıldığında; $\% 60$ 'ının yüksek (160-350 mg kg-1), \%30'unun çok yüksek (>350 mg kg-1) ve \%10'unun da orta düzeyde magnezyum içerdikleri belirlenmiştir. İkinci toprak örneklerinin de; \%75 yüksek, \%15 çok yüksek ve \%10 orta düzeyde alınabilir $\mathrm{Mg}$ içerdiği gözlemlenmiştir. Toprakların magnezyum elementi içeriklerinde çok fazla bir değişim analiz edilmemiştir. Benzer bulgular Kaplan ve ark. (1995) ile Sönmez ve Kaplan (2007) tarafından da bildirilmiştir.

\section{Toplam azot ve alınabilir fosfor}

Araştırılan toprak örneklerinin toplam azot ve alınabilir fosfor elementi analiz sonuçları Çizelge 4'de verilmiştir. Toprakların toplam azot içeriklerinin üretim öncesi ve sonrası olmak üzere sırasıyla; $\% 0.084-0.280$ ve \%0.078-0.347 arasında değiştiği belirlenmiştir. Sera topraklarının üretim sezonu öncesi toplam azot içeriği sınıflandırması yapıldığında (Kovancı, 1985); \%60'ının zengin (\%0.15<), \%30'unun iyi (\%0.1-0.15) ve \%10'unun orta düzeyde (\%0.05-0.1) azot içerdiği belirlenmiştir. Bu dağılım üretim sezonu sonrası; \% 35 zengin, \%45 iyi ve \%20 orta düzeyde azot içeriği şeklinde değişmiştir. Toprakların azot içerikleri bitkisel üretim sonunda zengin olan topraklarda düşüş gösterirken orta ve iyi olan topraklarda ise az da olsa artış göstermiştir. Toprakların alınabilir fosfor içerikleri $\left(\mathrm{NaH}_{2} \mathrm{CO}_{3}\right.$ ile ekstrakte edilmiş), üretim sezonu başında ve bitiminde sırasıyla; 30.6-228.7 $\mathrm{mg} \mathrm{kg}^{-1}$ ve 25.2-127.3 $\mathrm{mg} \mathrm{kg}^{-1}$ aralığında değişim göstermiştir. Sillanpää (1990)'a göre; ürün yetiştirme öncesi toprakların \% 80'i çok fazla (>80 mg kg-1), \% 20'si ise fazla düzeyde $\left(25-80 \mathrm{mg} \mathrm{kg}^{-1}\right)$ alınabilir fosfor içerdiği belirlenmiştir. Bu durum, üretim sonunda $\% 60$ oranında fazla ve \%40 oranında çok fazla fosfor içeriği şeklinde dağılım göstermiştir. Sera topraklarındaki fosfor miktarının üretim sonrası bile fazla düzeylerde analiz edilmesi gübreleme uygulamalarının bilimsellikten uzak bir şekilde yapıldığının da göstergesidir. 
Çizelge 4. Sera topraklarının toplam $\mathrm{N}$ ve alınabilir $\mathrm{P}$ içerikleri Table 4. Total $N$ and available $P$ contents of greenhouse soils

\begin{tabular}{|c|c|c|c|c|}
\hline \multirow{2}{*}{ Sera No } & \multicolumn{2}{|c|}{ Üretim Sezonu Öncesi } & \multicolumn{2}{|c|}{ Üretim Sezonu Sonrası } \\
\hline & N (\%) & $P\left(\mathrm{mg} \mathrm{kg}^{-1}\right)$ & N (\%) & $P\left(\mathrm{mg} \mathrm{kg}^{-1}\right)$ \\
\hline 1 & 0.157 & 174.8 & 0.123 & 98.9 \\
\hline 2 & 0.280 & 187.4 & 0.347 & 127.3 \\
\hline 3 & 0.179 & 148.3 & 0.179 & 88.3 \\
\hline 4 & 0.157 & 115.1 & 0.129 & 50.4 \\
\hline 5 & 0.123 & 41.0 & 0.095 & 27.8 \\
\hline 6 & 0.129 & 182.0 & 0.084 & 50.8 \\
\hline 7 & 0.179 & 215.6 & 0.157 & 107.7 \\
\hline 8 & 0.213 & 228.7 & 0.218 & 116.7 \\
\hline 9 & 0.224 & 157.4 & 0.207 & 109.4 \\
\hline 10 & 0.118 & 83.3 & 0.084 & 66.8 \\
\hline 11 & 0.118 & 170.4 & 0.101 & 68.6 \\
\hline 12 & 0.095 & 30.6 & 0.146 & 58.4 \\
\hline 13 & 0.112 & 110.4 & 0.129 & 38.0 \\
\hline 14 & 0.084 & 82.1 & 0.106 & 52.0 \\
\hline 15 & 0.112 & 51.6 & 0.078 & 25.2 \\
\hline 16 & 0.168 & 208.0 & 0.106 & 82.5 \\
\hline 17 & 0.252 & 215.3 & 0.196 & 79.0 \\
\hline 18 & 0.168 & 142.5 & 0.151 & 44.1 \\
\hline 19 & 0.151 & 74.0 & 0.118 & 46.1 \\
\hline 20 & 0.185 & 169.3 & 0.129 & 89.5 \\
\hline Ort. & 0.160 & 139.4 & 0.145 & 71.3 \\
\hline V.K. & 32.6 & 44.6 & 43.7 & 42.5 \\
\hline S.S. & 0.06 & 62.1 & 0.06 & 30.3 \\
\hline Min. & 0.084 & 30.6 & 0.078 & 25.2 \\
\hline Mak. & 0.280 & 228.7 & 0.347 & 127.3 \\
\hline
\end{tabular}

Ort: Ortalama; V.K.: Varyasyon Katsayısı; S.S.: Standart Sapma; Min.: Minimum; Mak.: Maksimum

Alınabilir mikro besin elementleri ( $\mathrm{Fe}, \mathrm{Cu}, \mathrm{Mn}$ ve $\mathrm{Zn}$ ) Sera topraklarının alınabilir mikro besin elementlerine ait analiz sonuçları Çizelge $5^{\prime}$ de sunulmuştur. Birinci ve ikinci toprak örneklemesinde belirlenen alınabilir demir içerikleri (DTPA-dietilen triamin pentaasetik asit ile ekstrakte edilebilir) sırasıyla; $8.6-59.6$ ve $6.4-32.5 \mathrm{mg} \mathrm{kg}$ karalığında $^{-1}$ değişmiştir. Bu toprakların demir içerikleri Lindsay and
Norvell (1978)'e göre yeterli $\left(>4.5 \mathrm{mg} \mathrm{kg}^{-1}\right.$ ) olarak sınıflandırılabilmektedir. Toprakların bakır içeriklerinin üretim öncesi ve sonrası sırasıyla; 0.3-34.7 ve 0.4-25.8 $\mathrm{mg} \mathrm{kg}^{-1}$ aralığında değiştiği analiz edilmiştir. Alınabilir bakır analiz sonuçlarının tamamı Lindsay and Norvell (1978)'e göre sınıflandırıldığında bitki besin elementinden yararlanılabilecek yeterlilik sınırının üstünde $\left(>0.2 \mathrm{mg} \mathrm{kg}^{-1}\right)$ olduğu gözlenmiştir.

Çizelge 5. Sera topraklarının alınabilir mikro element içerikleri Table 5. Available micro nutrient contents of greenhouse soils

\begin{tabular}{|c|c|c|c|c|c|c|c|c|}
\hline \multirow{3}{*}{ Sera No } & \multicolumn{4}{|c|}{ Üretim Sezonu Öncesi } & \multicolumn{4}{|c|}{ Üretim Sezonu Sonrası } \\
\hline & $\mathbf{F e}$ & $\mathbf{C u}$ & Zn & Mn & Fe & Cu & Zn & Mn \\
\hline & \multicolumn{4}{|c|}{$\left(\mathbf{m g ~ k g}^{-1}\right)$} & \multicolumn{4}{|c|}{$\left(\mathbf{m g ~ k g}^{-1}\right)$} \\
\hline 1 & 22.8 & 1.9 & 0.6 & 69.0 & 11.3 & 1.1 & 5.4 & 19.3 \\
\hline 2 & 22.2 & 24.8 & 0.5 & 20.2 & 6.4 & 7.6 & 4.8 & 7.0 \\
\hline 3 & 58.9 & 34.7 & 0.3 & 39.8 & 14.4 & 25.8 & 5.5 & 5.4 \\
\hline 4 & 20.0 & 23.8 & 1.1 & 23.4 & 23.7 & 24.7 & 8.5 & 15.2 \\
\hline 5 & 59.7 & 2.2 & 0.3 & 28.7 & 20.0 & 4.3 & 2.8 & 12.1 \\
\hline 6 & 40.1 & 3.8 & 1.3 & 125.6 & 21.9 & 1.8 & 3.9 & 31.5 \\
\hline 7 & 28.0 & 15.3 & 0.7 & 24.0 & 20.0 & 12.7 & 4.0 & 2.6 \\
\hline 8 & 23.3 & 9.9 & 3.3 & 43.9 & 17.3 & 8.9 & 4.6 & 42.5 \\
\hline 9 & 17.0 & 1.7 & 0.5 & 17.7 & 17.1 & 2.4 & 5.1 & 33.6 \\
\hline 10 & 33.6 & 2.4 & 0.3 & 43.3 & 19.0 & 2.7 & 2.3 & 55.5 \\
\hline 11 & 17.3 & 5.0 & 0.3 & 30.5 & 15.5 & 3.0 & 4.6 & 6.9 \\
\hline 12 & 16.7 & 1.0 & 0.1 & 33.6 & 18.0 & 0.8 & 1.8 & 33.0 \\
\hline 13 & 16.8 & 4.4 & 0.4 & 41.4 & 15.0 & 8.7 & 6.5 & 34.0 \\
\hline 14 & 49.2 & 3.1 & 0.4 & 53.6 & 28.2 & 3.4 & 4.7 & 64.9 \\
\hline 15 & 8.6 & 0.4 & 0.2 & 22.2 & 15.3 & 0.4 & 3.4 & 11.0 \\
\hline 16 & 21.5 & 2.6 & 0.3 & 46.8 & 26.0 & 2.2 & 4.6 & 39.2 \\
\hline 17 & 16.7 & 4.8 & 0.6 & 38.4 & 17.0 & 5.2 & 4.1 & 6.5 \\
\hline 18 & 11.0 & 1.4 & 0.5 & 34.4 & 14.9 & 7.8 & 6.3 & 27.9 \\
\hline 19 & 15.0 & 0.9 & 0.2 & 24.9 & 31.4 & 3.7 & 4.5 & 20.9 \\
\hline 20 & 10.3 & 1.0 & 0.4 & 35.3 & 32.5 & 2.7 & 6.7 & 67.8 \\
\hline Ort. & 25.4 & 7.26 & 0.62 & 39.8 & 19.2 & 6.5 & 4.7 & 26.8 \\
\hline V.K. & 59.8 & 133.7 & 113.2 & 59.6 & 33.9 & 110.5 & 33.3 & 73.7 \\
\hline S.S. & 15.2 & 9.6 & 0.6 & 23.7 & 6.5 & 7.1 & 1.5 & 19.7 \\
\hline Min. & 8.6 & 0.3 & 0.1 & 17.7 & 6.4 & 0.4 & 1.8 & 2.6 \\
\hline Mak. & 59.6 & 34.7 & 3.3 & 125.6 & 32.5 & 25.8 & 8.5 & 67.8 \\
\hline
\end{tabular}

Ort: Ortalama; V.K.: Varyasyon Katsayısı; S.S.: Standart Sapma; Min.: Minimum; Mak.: Maksimum 
Üretim öncesinde toprakların çinko içerikleri 0.1 ile $3.3 \mathrm{mg} \mathrm{kg}^{-1}$ aralığında değişmiştir. Üretim sonrası ise 1.8 ile $8.5 \mathrm{mg} \mathrm{kg}^{-1}$ arasında değişen çinko değerleri belirlenmiştir. Lindsay and Norvell (1978)'e göre; üretim sezonu öncesi toprakların \% 55'i düşük miktarda $(<0.5$ $\mathrm{mg} \mathrm{kg}^{-1}$ ) ve bitkide eksiklik belirtilerinin gözlenebileceği seviyelerde çinko içermekte olup bu toprakların \% 30'u orta (0.5-1 mg kg-1), \% 15'i de fazla miktarda $\left(>1 \mathrm{mg} \mathrm{kg}^{-1}\right)$ alınabilir çinko içeren topraklar olarak dağılım göstermiştir. Üretim öncesi toprakların çinko içeriklerinin düşük miktarda olması, çinko ile kireç ve fosfor arasındaki antagonistik ilişkiden ve yetersiz düzeydeki çinkolu gübre uygulamalarından kaynaklandığı düşünülmekte-dir. Toprak örneklerinin alınabilir mangan içeriği üretim öncesi ve sonrası olmak üzere sırasılya; $17.7-125.6 \mathrm{mg} \mathrm{kg}^{-1}$ ve $2.6-67.8 \mathrm{mg} \mathrm{kg}^{-1}$ değerleri arasında değişim göstermiştir. Alınabilir mangan sonuçları Lindsay and Norvell (1978)'e göre sınıflandııılığında örneklerin tamamının yeterli $(>1.2$ $\mathrm{mg} \mathrm{kg}^{-1}$ ) sınıfına dâhil olduğu ve mangan bakımından bir beslenme sorununun bulunmadığı gözlenmiştir. Kaplan ve ark. (1995), Kumluca ve Finike yöreleri domates seraları toprak örneklerinin alınabilir mangan içerikleri yönünden yeterli olduğunu belirlemiştir. Sönmez ve Kaplan (2007), ise toprak örneklerinin alınabilir mangan içeriklerinin $0-20 \mathrm{~cm}$ toprak derinliğinde 2.7-11.3 ppm ve $20-40 \mathrm{~cm}$ toprak derinliğinde 1.9-13.8 ppm arasında değiştiğini ve yeterli sınıfına dahil olduğunu belirlemiştir.

\section{Toprakların toplam ağır metal içerikleri}

Sera topraklarının ağır metal içerikleri, vejetasyon sonunda alınan toprak örnekleri üzerinden belirlenmiştir (Çizelge 6). Bu seçimin temel sebebi, sera gibi kapalı bir sistemde ağır metal bulaşıklığının ancak gübreler ve sulama sularından kaynaklanabilmesi ve bu bulaşıklığın birikimi sonucu, ağır metallerin toksik etkilerinin tarımsal üretimde olumsuzluklara yol açması durumunun kısa dönemde gözlenememesidir. Çevre ve Şehircilik Bakanlığı (2015) tarafından belirlenen ağır metal konsantrasyonlarının sınır değerleri Çizelge 7'de verilmiştir. Çizelge 6'ya göre, 7 numaralı sera toprağının (pH:7.46), $162.3 \mathrm{mg} \mathrm{kg}^{-1}$ toplam krom konsantrasyonu ile sınır değeri $\left(100 \mathrm{mg} \mathrm{kg}^{-1}\right)$ aştığı gözlenmektedir. 4 numaralı $(\mathrm{pH}: 7.63)$ ve 7 numaralı sera topraklarının toplam nikel konsantrasyonu sırasıyla; 103.3 ve $104.6 \mathrm{mg}$ $\mathrm{kg}^{-1}$ ile belirlenen sınır değerini (100 $\left.\mathrm{mg} \mathrm{kg}^{-1}\right)$ aştığı analiz edilmiştir. 4 ve 7 numaralı sera toprakları dışında toplam ağır metal konsantrasyonlarına ait belirlenmiş herhangi bir sınır değeri aşan üretici toprağı bulunmamaktadır. Özkan (2008), domates seralarında yürüttüğü tez çalışmasında toprakların Cd içeriklerinin 0.49-2.61 mg $\mathrm{kg}^{-1}$, Ni içeriklerinin 22-244.1 $\mathrm{mg} \mathrm{kg}^{-1}$ ve $\mathrm{Pb}$ içeriklerinin 2.94-23.9 $\mathrm{mg} \mathrm{kg}^{-1}$ arasında değiştiğini belirlemiştir.
Çizelge 6. Sera topraklarının toplam ağır metal içerikleri Table 6. Total heavy metal contents of greenhouse soils

\begin{tabular}{|c|c|c|c|c|c|}
\hline \multirow{2}{*}{ Sera No } & $\mathrm{Cr}$ & Cd & Co & $\mathbf{P b}$ & $\mathbf{N i}$ \\
\hline & \multicolumn{5}{|c|}{$\left(\mathrm{mg} \mathrm{kg}^{-1}\right)$} \\
\hline 1 & 43.3 & 0.20 & 12.7 & 57.0 & 34.0 \\
\hline 2 & 44.2 & 0.28 & 10.4 & 46.3 & 27.1 \\
\hline 3 & 44.9 & 0.18 & 9.3 & 55.8 & 33.7 \\
\hline 4 & 82.0 & 1.03 & 18.9 & 45.2 & 103.3 \\
\hline 5 & 33.8 & 0.03 & 6.3 & 26.7 & 22.8 \\
\hline 6 & 32.2 & 0.15 & 8.2 & 66.2 & 28.7 \\
\hline 7 & 162.3 & 0.25 & 18.5 & 93.3 & 104.6 \\
\hline 8 & 39.1 & 0.35 & 8.0 & 68.3 & 30.7 \\
\hline 9 & 48.5 & 0.15 & 10.1 & 54.0 & 48.9 \\
\hline 10 & 30.4 & 0.17 & 9.8 & 56.2 & 30.9 \\
\hline 11 & 40.3 & 0.12 & 8.9 & 31.0 & 68.3 \\
\hline 12 & 23.9 & 0.27 & 8.4 & 55.2 & 28.1 \\
\hline 13 & 40.2 & 0.27 & 10.1 & 63.8 & 21.2 \\
\hline 14 & 35.4 & 0.30 & 8.8 & 54.5 & 33.7 \\
\hline 15 & 31.7 & 0.15 & 4.3 & 31.7 & 23.2 \\
\hline 16 & 30.7 & 0.13 & 5.2 & 31.0 & 24.8 \\
\hline 17 & 54.4 & 0.38 & 10.6 & 67.7 & 38.5 \\
\hline 18 & 49.3 & 0.43 & 11.8 & 74.0 & 41.9 \\
\hline 19 & 38.0 & 0.83 & 6.6 & 58.0 & 34.0 \\
\hline 20 & 37.4 & 0.20 & 7.0 & 55.8 & 33.3 \\
\hline Ort. & 47.1 & 0.29 & 9.7 & 54.6 & 40.6 \\
\hline V.K. & 63.1 & 155.8 & 38.1 & 29.8 & 59.3 \\
\hline S.S. & 29.7 & 0.7 & 3.73 & 16.3 & 24.0 \\
\hline Min. & 23.9 & 0.03 & 4.3 & 31.0 & 21.2 \\
\hline Mak. & 82.0 & 1.03 & 18.9 & 93.3 & 104.6 \\
\hline
\end{tabular}

Ort: Ortalama; V.K.: Varyasyon Katsayısı; S.S.: Standart Sapma Min.: Minimum; Mak.: Maksimum

Çizelge 7. Toprakta izin verilebilir ağır metal sınır değerleri (T.C. Çevre ve Şehircilik Bakanlığı, 2015)

Table 7. Limit values of heavy metals in soil (T.C. Çevre ve Şehircilik Bakanlığı, 2015)

\begin{tabular}{|c|c|c|}
\hline \multirow{2}{*}{$\begin{array}{l}\text { Ağır Metal } \\
\text { (Toplam) }\end{array}$} & $6 \leq \mathrm{pH}<7$ & $\mathrm{pH} \geq 7$ \\
\hline & \multicolumn{2}{|c|}{$\left(\mathrm{mg} \mathrm{kg}^{-1}\right)$} \\
\hline $\mathrm{Pb}$ & 70 & 100 \\
\hline $\mathrm{Cd}$ & 1 & 1.5 \\
\hline $\mathrm{Cr}$ & 60 & 100 \\
\hline $\mathrm{Cu}$ & 50 & 100 \\
\hline $\mathrm{Ni}$ & 50 & 70 \\
\hline $\mathrm{Zn}$ & 150 & 200 \\
\hline $\mathrm{Hg}$ & 0.5 & 1 \\
\hline
\end{tabular}

\section{Su örneklerinin kimyasal özellikleri}

Üretim sezonu öncesi, ortası ve sonrası alınan sulama suyu örneklerinin kimyasal özellikleri sırasıyla Çizelge 8,9 ve $10^{\prime}$ da verilmiştir. Su örneklerinde belirlenen $\mathrm{pH}$ değerleri, 6.48 ile 7.66 arasında değişim göstermektedir (Çizelge $8,9,10$ ). Ortalama pH değeri ise 7.13'dür. Sulama suları için 6.5-8.4 pH aralığı sorun yaratmamaktadır (Ayers and Wescot, 1989). Araştırma konusu suların tamamında $\mathrm{pH}$ ortalama değeri standart değerler arasında olduğundan kullanılabilir sulama suyu sınıfına girmektedir. Sulama sularında $\mathrm{pH}$ değerinin sınır değerlerden farklı olması bitkilerde dengesiz beslenme veya toksik maddelerin birikimine neden olmaktadır (Kanber ve ark., 2003). 
Çerçioğlu ve ark.

Çizelge 8. Sera sulama sularının kimyasal özellikleri (1. dönem)

Table 8. Chemical characteristics of greenhouse irrigation water (1.period)

\begin{tabular}{|c|c|c|c|c|c|c|c|c|c|c|c|c|c|}
\hline $\begin{array}{c}\text { Sera } \\
\text { No }\end{array}$ & pH & $\begin{array}{c}\text { EC } \\
\left(\mu S \mathrm{~cm}^{-1}\right)\end{array}$ & $\mathrm{Na}^{+}$ & $\mathbf{K}^{+}$ & $\mathrm{Ca}^{+2}+\mathrm{Mg}^{+2}$ & $\begin{array}{c}\text { TK } \\
\left(\mathrm{me} \mathrm{l}^{-1}\right)\end{array}$ & $\mathrm{HCO}_{3}^{-}$ & $\mathrm{Cl}^{-}$ & $\mathrm{SO}_{4}^{-2}$ & TA & SAR & RSC & $\begin{array}{c}\text { B } \\
\left(\mathrm{mg} \mathrm{kg}^{-1}\right)\end{array}$ \\
\hline 1 & 6.74 & 540 & 1.22 & 0.13 & 3.90 & 5.26 & 2.70 & 1.50 & 1.14 & 5.34 & 0.88 & - & 0.18 \\
\hline 2 & 6.92 & 616 & 1.58 & 0.18 & 4.36 & 6.13 & 3.90 & 1.00 & 1.23 & 6.13 & 1.07 & - & 0.28 \\
\hline 3 & 7.17 & 621 & 1.49 & 0.16 & 4.56 & 6.21 & 5.10 & 1.00 & 0.05 & 6.15 & 0.99 & - & 0.07 \\
\hline 4 & 7.5 & 623 & 0.57 & 0.13 & 5.43 & 6.13 & 4.00 & 1.00 & 1.10 & 6.10 & 0.34 & - & 0.07 \\
\hline 5 & 6.48 & 502 & 1.00 & 0.16 & 3.85 & 5.01 & 2.79 & 1.00 & 1.14 & 4.93 & 0.72 & - & 0.43 \\
\hline 6 & 6.85 & 744 & 1.25 & 0.60 & 5.55 & 7.41 & 5.20 & 1.00 & 1.10 & 7.30 & 0.75 & - & 0.34 \\
\hline 7 & 7.46 & 621 & 0.58 & 0.13 & 5.40 & 6.11 & 4.81 & 1.25 & 0.05 & 6.11 & 0.35 & - & 0.17 \\
\hline 8 & 7.41 & 617 & 1.55 & 0.18 & 4.43 & 6.17 & 3.84 & 1.00 & 1.23 & 6.07 & 1.04 & - & 0.28 \\
\hline 9 & 6.89 & 630 & 1.58 & 0.18 & 4.45 & 6.22 & 3.95 & 1.00 & 1.23 & 6.18 & 1.06 & - & 0.23 \\
\hline 10 & 7.45 & 626 & 1.60 & 0.18 & 4.40 & 6.18 & 3.69 & 1.25 & 1.23 & 6.17 & 1.08 & - & 0.21 \\
\hline 11 & 7.31 & 620 & 1.58 & 0.18 & 4.33 & 6.10 & 3.97 & 1.00 & 1.23 & 6.20 & 1.08 & - & 0.23 \\
\hline 12 & 7.07 & 629 & 1.55 & 0.18 & 4.50 & 6.24 & 3.95 & 1.00 & 1.23 & 6.18 & 1.04 & - & 0.26 \\
\hline 13 & 6.6 & 678 & 1.43 & 0.21 & 4.91 & 6.56 & 3.60 & 2.00 & 1.15 & 6.75 & 0.91 & - & 0.55 \\
\hline 14 & 6.8 & 538 & 1.28 & 0.11 & 3.95 & 5.34 & 2.76 & 1.50 & 1.12 & 5.38 & 0.91 & - & 0.20 \\
\hline 15 & 6.65 & 618 & 1.57 & 0.45 & 4.12 & 6.13 & 3.14 & 1.25 & 1.23 & 5.62 & 1.09 & - & 0.51 \\
\hline 16 & 6.61 & 606 & 1.57 & 0.18 & 4.28 & 6.03 & 3.24 & 1.50 & 1.23 & 5.97 & 1.07 & - & 0.24 \\
\hline 17 & 7.11 & 612 & 1.57 & 0.24 & 4.20 & 6.00 & 3.32 & 1.50 & 1.23 & 6.05 & 1.08 & - & 0.26 \\
\hline 18 & 6.8 & 616 & 1.57 & 0.18 & 4.38 & 6.13 & 3.00 & 1.75 & 1.23 & 5.98 & 1.06 & - & 0.51 \\
\hline 19 & 6.83 & 621 & 1.58 & 0.18 & 4.45 & 6.22 & 3.41 & 1.50 & 1.23 & 6.14 & 1.06 & - & 0.30 \\
\hline Ort. & 6.98 & 614.6 & 1.37 & 0.21 & 4.50 & 6.08 & 3.70 & 1.26 & 1.07 & 6.04 & 0.93 & & 0.28 \\
\hline V.K. & 4.6 & 8.2 & 23.7 & 56.8 & 10.9 & 8.2 & 19.8 & 24.2 & 33.8 & 8.3 & 24.9 & & 48.6 \\
\hline S.S. & 0.3 & 50.4 & 0.3 & 0.1 & 0.5 & 0.5 & 0.7 & 0.3 & 0.3 & 0.5 & 0.2 & & 0.13 \\
\hline Min. & 6.48 & 502 & 1.60 & 0.11 & 3.85 & 5.01 & 2.70 & 1.00 & 0.05 & 4.93 & 0.34 & & 0.07 \\
\hline Mak. & 7.50 & 744 & 0.57 & 0.60 & 5.55 & 7.41 & 5.20 & 2.00 & 1.23 & 7.30 & 1.09 & & 0.55 \\
\hline
\end{tabular}

TK: Toplam Katyon; TA: Toplam Anyon; Ort: Ortalama; V.K.: Varyasyon KatsayısI; S.S.: Standart Sapma; Min.: Minimum; Mak.: Maksimum

Çizelge 9. Sera sulama sularının kimyasal özellikleri (2. dönem)

Table 9. Chemical characteristics of greenhouse irrigation water (2.period)

\begin{tabular}{|c|c|c|c|c|c|c|c|c|c|c|c|c|c|}
\hline $\begin{array}{c}\text { Sera } \\
\text { No }\end{array}$ & pH & $\begin{array}{c}\mathrm{EC} \\
\left(\mu \mathrm{S} \mathrm{cm}^{-1}\right)\end{array}$ & $\mathrm{Na}^{+}$ & $\mathbf{K}^{+}$ & $\mathrm{Ca}^{+2}+\mathrm{Mg}^{+2}$ & $\begin{array}{c}\text { TK } \\
\left(\mathrm{me} \mathrm{l}^{-1}\right) \\
\end{array}$ & $\mathrm{HCO}_{3}^{-}$ & $\mathrm{Cl}^{-}$ & $\mathrm{SO}_{4}^{-2}$ & TA & SAR & RSC & $\begin{array}{c}\text { B } \\
\left(\mathrm{mg} \mathrm{kg}^{-1}\right)\end{array}$ \\
\hline 1 & 6.72 & 515 & 1.27 & 0.04 & 3.75 & 5.05 & 2.63 & 1.24 & 1.1 & 4.97 & 0.92 & - & iz \\
\hline 2 & 7.41 & 598 & 1.61 & 0.05 & 4.20 & 5.86 & 3.40 & 1.24 & 1.18 & 5.82 & 1.11 & - & 0.23 \\
\hline 3 & 7.19 & 612 & 0.62 & 0.04 & 5.30 & 5.95 & 4.95 & 0.99 & 0.06 & 6.01 & 0.38 & - & 0.02 \\
\hline 4 & 7.25 & 610 & 0.62 & 0.04 & 5.245 & 5.91 & 4.68 & 1.24 & 1.12 & 7.04 & 0.38 & - & $i z$ \\
\hline 5 & 7.21 & 478 & 1.03 & 0.05 & 3.54 & 4.62 & 2.60 & 0.99 & 1.08 & 4.67 & 0.78 & - & $i z$ \\
\hline 6 & 6.98 & 777 & 1.28 & 0.16 & 6.20 & 7.64 & 4.90 & 1.74 & 1.1 & 7.74 & 0.73 & - & 0.46 \\
\hline 7 & 6.92 & 614 & 1.31 & 0.05 & 4.60 & 5.96 & 4.80 & 1.24 & 0.06 & 6.10 & 0.87 & - & 0.29 \\
\hline 8 & 7.09 & 605 & 1.57 & 0.04 & 4.30 & 5.92 & 4.08 & 0.74 & 1.2 & 6.02 & 1.07 & - & 0.61 \\
\hline 9 & 6.66 & 605 & 1.57 & 0.05 & 4.35 & 5.97 & 3.55 & 1.24 & 1.2 & 5.99 & 1.07 & - & 0.09 \\
\hline 10 & 7.58 & 609 & 1.57 & 0.05 & 4.35 & 5.97 & 3.53 & 1.24 & 1.18 & 5.95 & 1.07 & - & 0.06 \\
\hline 11 & 6.94 & 607 & 1.54 & 0.05 & 4.30 & 5.89 & 3.71 & 0.99 & 1.14 & 5.84 & 1.05 & - & 0.02 \\
\hline 12 & 7.01 & 606 & 1.61 & 0.05 & 4.28 & 5.94 & 3.55 & 1.24 & 1.18 & 5.97 & 1.10 & - & 0.17 \\
\hline 13 & 6.81 & 672 & 1.45 & 0.06 & 5.12 & 6.63 & 3.95 & 1.49 & 1.15 & 6.59 & 0.91 & - & 0.76 \\
\hline 14 & 7.54 & 554 & 1.34 & 0.02 & 4.05 & 5.42 & 2.80 & 1.49 & 1.15 & 5.44 & 0.94 & - & 0.10 \\
\hline 15 & 6.74 & 608 & 1.62 & 0.06 & 4.30 & 5.98 & 3.30 & 1.49 & 1.11 & 5.90 & 1.11 & - & 0.22 \\
\hline 16 & 7.27 & 588 & 1.61 & 0.06 & 4.08 & 5.74 & 3.65 & 0.99 & 1.15 & 5.79 & 1.12 & - & 0.13 \\
\hline 17 & 7.66 & 593 & 1.48 & 0.04 & 4.25 & 5.78 & 3.40 & 1.24 & 1.25 & 5.89 & 1.02 & - & 0.31 \\
\hline 18 & 7.19 & 607 & 1.61 & 0.05 & 4.28 & 5.94 & 3.80 & 0.99 & 1.23 & 6.02 & 1.10 & - & 0.19 \\
\hline 19 & 7.03 & 600 & 1.61 & 0.05 & 4.20 & 5.86 & 4.00 & 0.74 & 1.2 & 5.94 & 1.11 & - & 0.08 \\
\hline Ort. & 7.12 & 603 & 1.39 & 0.05 & 4.46 & 5.90 & 3.75 & 1.19 & 1.04 & 5.98 & 0.94 & & 0.23 \\
\hline V.K. & 4.1 & 9.7 & 22.7 & 49.0 & 13.8 & 9.9 & 18.9 & 21.5 & 33.4 & 10.9 & 24.4 & & 108.2 \\
\hline S.S. & 0.3 & 58.4 & 0.3 & 0.03 & 0.6 & 0.6 & 0.7 & 0.3 & 0.3 & 0.7 & 0.2 & & 0.21 \\
\hline Min. & 6.66 & 478 & 0.617 & 0.025 & 3.54 & 4.62 & 2.60 & 0.74 & 0.06 & 4.67 & 0.38 & & 0 \\
\hline Mak. & 7.66 & 777 & 1.621 & 0.156 & 6.20 & 7.64 & 4.95 & 1.74 & 1.25 & 7.74 & 1.12 & & 0.76 \\
\hline
\end{tabular}

TK: Toplam Katyon; TA: Toplam Anyon; Ort: Ortalama; V.K.: Varyasyon Katsayısı; S.S.: Standart Sapma; Min.: Minimum; Mak.: Maksimum

Sulama sularının U.S. Salinity Laboratory (1954) sınıflandırma sistemine göre, seralarda kullanılan ve farklı kaynaklardan elde edilen sulama suları içerisinde yalnızca 6 numaralı üreticinin kullandığı kuyu suyu, tuzluluk (750-2000 $\mu \mathrm{S} \mathrm{cm}^{-1}$ ) ve sodyum adsorbsiyon oranı (0-10 SAR) sınıfları ile C3S1 sınıfı sulama sularına dahil olmaktadır. Geri kalan sulama suyu örneklerinin tuzluluk ve SAR sınıfları sırasıyla $250-750 \mu \mathrm{S} \mathrm{cm}^{-1}$ ve
0-10 SAR ile bu örneklerin tamamının C2S1 sınıfı sulama suları olduğu belirlenmiştir. Bor, bitkilerin beslenmesinde esas element olmasına rağmen sulama sularında $0.5 \mathrm{mg} \mathrm{kg}^{-1}$ den fazla konsantrasyonları bazı bitkilere zararlı olabilir. Bor konsantrasyonu $4 \mathrm{mg}$ $\mathrm{kg}^{1}$ 'den fazla olan sulama suları bütün bitkilere toksiktirler (Ayyıldız, 1983). İncelenen su örneklerinin bor sonuçlarının iz ile $0.76 \mathrm{mg} \mathrm{kg}^{-1}$ konsantrasyonları 
(Çizelge $8,9,10$ ) arasında olduğu ve genelde 1.sınıf (çok iyi) ve 2 . Sınıf (iyi) sulama suyu sınıfı olduğu için sulama suyu olarak kullanımında bor açısından bir sakınca olmadığı gözlenmiştir. Üreticiler tarafından kullanılan sulama sularının yağmurlama, damlama ya da salma sulama ile verilmesinde içerdikleri anyon ve katyonlar açısından bir sakınca yoktur. Scofield (1935)'e göre $\mathrm{Cl}^{-}$ve $\mathrm{SO}_{4}^{-2}$ anyonları bakımından tüm dönemlerin sulama suları, çok iyi $\left(<4 \mathrm{me}^{-1}\right)$ sulama suyu sınıfındadır.

Çizelge 10. Sera sulama sularının kimyasal özellikleri (3. dönem)

Table 10. Chemical characteristics of greenhouse irrigation water (3.period)

\begin{tabular}{|c|c|c|c|c|c|c|c|c|c|c|c|c|c|}
\hline \multirow[t]{2}{*}{ Sera No } & \multirow[t]{2}{*}{ pH } & \multirow{2}{*}{$\begin{array}{c}\text { EC } \\
\left(\mu \mathrm{cm}^{-1}\right)\end{array}$} & $\mathrm{Na}^{+}$ & $\mathbf{K}^{+}$ & $\mathrm{Ca}^{+2}+\mathrm{Mg}^{+2}$ & TK & $\mathrm{HCO}_{3}{ }^{-}$ & $\mathrm{Cl}^{-}$ & $\mathrm{SO}_{4}^{-2}$ & TA & \multirow[t]{2}{*}{ SAR } & \multirow[t]{2}{*}{ RSC } & \multirow{2}{*}{$\begin{array}{c}B \\
\left(\mathrm{mg} \mathrm{kg}^{-1}\right)\end{array}$} \\
\hline & & & \multicolumn{8}{|c|}{$\left(\mathrm{me} \mathrm{l}^{-1}\right)$} & & & \\
\hline 1 & 7.00 & 602 & 1.29 & 0.05 & 4.65 & 5.99 & 3.75 & 0.99 & 1.10 & 5.84 & 0.84 & - & 0.28 \\
\hline 2 & 7.25 & 612 & 1.44 & 0.11 & 4.40 & 5.95 & 3.50 & 1.24 & 1.15 & 5.89 & 0.97 & - & 0.10 \\
\hline 3 & 7.25 & 615 & 1.09 & 0.14 & 4.88 & 6.11 & 5.10 & 0.99 & 0.06 & 6.15 & 0.69 & - & 0.16 \\
\hline 4 & 7.44 & 633 & 0.99 & 0.05 & 5.20 & 6.24 & 5.00 & 1.24 & 1.10 & 7.34 & 0.62 & - & 0.28 \\
\hline 5 & 7.30 & 495 & 1.03 & 0.10 & 3.83 & 4.96 & 2.50 & 1.24 & 1.14 & 4.88 & 0.74 & - & 0.22 \\
\hline 6 & 7.28 & 634 & 1.04 & 0.38 & 4.70 & 6.12 & 4.49 & 0.74 & 1.05 & 6.28 & 0.68 & - & 0.20 \\
\hline 7 & 7.39 & 636 & 1.07 & 0.09 & 5.20 & 6.36 & 4.98 & 1.24 & 0.06 & 6.28 & 0.66 & - & 0.24 \\
\hline 8 & 7.30 & 635 & 1.26 & 0.11 & 4.80 & 6.18 & 4.05 & 0.99 & 1.20 & 6.24 & 0.82 & - & 0.13 \\
\hline 9 & 7.26 & 617 & 1.08 & 0.12 & 4.80 & 6.00 & 3.85 & 0.99 & 1.20 & 6.04 & 0.70 & - & 0.07 \\
\hline 10 & 7.28 & 610 & 1.09 & 0.12 & 4.80 & 6.00 & 3.65 & 0.99 & 1.30 & 5.95 & 0.70 & - & 0.16 \\
\hline 11 & 7.26 & 615 & 1.36 & 0.12 & 4.50 & 5.98 & 3.52 & 1.24 & 1.28 & 6.04 & 0.91 & - & 0.09 \\
\hline 12 & 7.35 & 635 & 1.08 & 0.12 & 4.90 & 6.10 & 4.03 & 0.99 & 1.25 & 6.27 & 0.69 & - & 0.21 \\
\hline 13 & 6.96 & 562 & 1.34 & 0.14 & 4.10 & 5.58 & 3.10 & 1.24 & 1.15 & 5.49 & 0.94 & - & 0.33 \\
\hline 14 & 7.22 & 607 & 1.41 & 0.06 & 4.60 & 6.08 & 3.17 & 1.74 & 1.10 & 6.01 & 0.93 & - & 0.03 \\
\hline 15 & 7.61 & 625 & 1.69 & 0.25 & 4.30 & 6.25 & 3.27 & 1.74 & 1.18 & 6.19 & 1.16 & - & 0.15 \\
\hline 16 & 7.20 & 622 & 1.09 & 0.12 & 4.80 & 6.01 & 4.04 & 0.74 & 1.30 & 6.08 & 0.70 & - & 0.20 \\
\hline 17 & 7.41 & 596 & 1.42 & 0.14 & 4.25 & 5.81 & 2.75 & 1.74 & 1.30 & 5.79 & 0.98 & - & 0.17 \\
\hline 18 & 7.30 & 618 & 1.49 & 0.12 & 4.43 & 6.03 & 3.28 & 1.49 & 1.22 & 5.99 & 1.00 & - & 0.26 \\
\hline 19 & 7.14 & 621 & 1.99 & 0.12 & 4.10 & 6.21 & 2.51 & 2.48 & 1.22 & 6.21 & 1.39 & - & 0.27 \\
\hline Ort. & 7.27 & 610 & 1.28 & 0.13 & 4.59 & 6.00 & 3.71 & 1.27 & 1.07 & 6.05 & 0.85 & & 0.19 \\
\hline V.K. & 2.0 & 5.4 & 20.6 & 57.4 & 8.0 & 5.1 & 21.2 & 33.2 & 34.0 & 7.5 & 23.4 & & 43.4 \\
\hline S.S. & 0.15 & 32.9 & 0.3 & 0.07 & 0.4 & 0.3 & 0.8 & 0.4 & 0.4 & 0.5 & 0.2 & & 0.08 \\
\hline Min. & 6.96 & 495 & 0.99 & 0.05 & 3.83 & 4.96 & 2.50 & 0.74 & 0.06 & 4.88 & 0.62 & & 0.03 \\
\hline Mak. & 7.61 & 636 & 1.29 & 0.38 & 5.20 & 6.36 & 5.10 & 2.48 & 1.25 & 7.34 & 1.39 & & 0.33 \\
\hline
\end{tabular}

TK: Toplam Katyon; TA: Toplam Anyon; Ort: Ortalama; V.K.: Varyasyon Katsayısl; S.S.: Standart Sapma; Min.: Minimum; Mak.: Maksimum

\section{SONUÇ}

Araştırmanın yapıldığı seralarda kullanılan sulama sularının kullanılabilir nitelikte olduğu ve gerekli kontroller yapıldığı takdirde sorun yaratmayacağı düşünülmektedir. Ancak yetiştirilecek bitki çeşidinin seçiminde $\mathrm{pH}$ değerleri göz önünde bulundurularak bir seçim yapılmalıdır. Topraklara uygulanan pestisit ve gübrelerin kalıntılarının yeraltı sularına, gölet, baraj vb. sulama suyu kaynaklarına karışması, yeraltı su seviyesinin alçalıp yükselmesi, yüzey sularına karışan endüstriyel ve evsel atıkların içerikleri, toprakların ve sulama sularının birçok özelliğini ( $\mathrm{pH}$ düşmesi, organik madde azalması, fosfor ve nitrat kirliliği vb.) olumsuz yönde etkilemektedir. Sürdürülebilir bir tarımsal üretim, toprağın fiziksel, kimyasal ve biyolojik özelliklerinin değişimine neden olan faktörlerin belirlenmesi ve gerekli önlemlerin alınması ile mümkün olabilmektedir. Seralarda daha iyi bir bitki gelişimi sağlanabilmesi için toprak analizlerine bağlı dengeli bir gübreleme programı düzenlenmesinin hem toprakların verim gücünü yükseltebileceği hem de besin maddelerinden kaynaklanan antagonistik etkileri önleyebileceği düşünülmektedir. Ayrıca sera topraklarına iyi yanmış ve öncesinde analizleri yapılmış olan ahır gübresi uygulamaları önerilmektedir.

\section{KAYNAKLAR}

Açıkgöz, E. 2001. Yem bitkileri. Uludağ Üniversitesi Güçlendirme Vakf1 Yayın No: 182. s. 41-66.

Akay, S. ve M. Kaplan. 1995. Kumluca ve Finike yörelerindeki seraların toprak tuzluluğu ve mevsimsel değişimi. İlhan Akalan Toprak ve Çevre Sempozyumu, Cilt:1, Yayın No: 7, Tübitak.

Ata, A. 2015. Örtüaltı domates yetiştiriciliği. Gıda, Tarım ve Hayvancılık Bakanlığı, Tarımsal Araştırmalar ve Politikalar Genel Müdürlüğ̈̈, Alata Bahçe Kültürleri Araştırma Enstitüsü, Erdemli-Mersin.
Atılgan, A., A. Coşkan, B. Saltuk ve M. Erkan. 2007. Antalya yöresindeki seralarda kimyasal ve organik gübre kullanım düzeyleri ve olası çevre etkileri. Ekoloji, 15(62): 37-47.

Ayers, R.S. and D.W. Wescot. 1989. Water Quality for Agriculture. FAO, Irrigation and Drainage, Paper No: 29, Rev. 1, Rome, Italy

Ayyıldız, M. 1983. Sulama Suyu Kalitesi ve Problemleri (İkinci baskı). Ankara Üniversitesi Ziraat Fakültesi Yayınları No: 879, 224 s. 
Bingham, F.T. 1982. Boron. In: Methods of Soil Analysis, Part 2: Chemical and Microbiological Properties. (Ed: A.L. Page), American Society of Agronomy, Madison, WI, USA, pp. 431-448.

Black, C.A. 1965. Methods of Soil Analysis, Part 1: Physical and Mineralogical Properties, including statistics of measurement and sampling. Agronomy Ser. 9. American Society of Agronomy, Inc. Publisher, Madison, Wisconsin, USA

Bremner, J.M. 1965. Total Nitrogen. In: Methods of Soil Analysis, Part 2 (Ed: C.A. Black), American Society of Agronomy, Inc. Publisher, Madison, Wisconsin, U.S.A, pp. 1149-1178.

Çamurcu, H. 2005. Dünya nüfus artışı ve getirdiği sorunlar. Balıkesir Üniversitesi Sosyal Bilimler Enstitüsü Dergisi, 8(3): 87-105.

Çerçioğlu, M., B. Okur, S. Delibacak ve A.R. Ongun. 2010. Bazı organik materyallerin toprağın makro besin element içeriği ve baş salata (Lactuca sativa L.var.capitata) verimine olan etkileri. Bitki Besleme ve Gübre Kongresi (15-17 Eylül, 2010, İmir) Bildirileri, Ege Üniversitesi Ziraat Fakültesi Dergisi, Özel Sayı. 5, s. 599-604.

Çevre ve Şehircilik Bakanlığı, 2015. Evsel ve kentsel arıtma çamurlarının tarımda kullanılmasına ilişkin yönetmelik, Ek-1A. 27661 no'lu Resmi Gazete.

Çolakoğlu, H. 1985. Sera yetiştiriciliğinde gübreleme. Toros Tarım Sanayi ve Ticaret A.Ş., Tarım Danışmanı. http://www.toros.com.tr/urunler. Erişim: Aralık 2012.

Evliya, H. 1964. Kültür Bitkilerinin Beslenmesi. Ankara Üniversitesi Ziraat Fakültesi Yayın No: 10.

Fageria, V.D. 2001. Nutrient interactions in crop plants. Journal of Plant Nutrition, 24: 1269-1290.

Fawzi, A.F.A. and M.M. El-Fouly. 1980. Soil and Leaf Analysis of Potassium in Different Areas in Egypt. Role of Potassium Crop Production, IPI, Bern, pp. 73-80.

Jackson, M.L. 1958. Soil Chemical Analysis. Prentice Hall of Englewood cliffs, New Jersey, USA

Kacar, B. 1962. Plant and Soil Analysis. University of Nebraska College of Agriculture, Department of Agronomy. Licoln, Nebraska, USA.

Kanber, R., R. Çakır ve A.F. Tarı. 2003. Sulama ve Drenaj Mühendisliği. Tarım ve Köy İşleri Bakanlığı, Köy Hizmetleri Genel Müdürlüğü, Toprak ve Su Kaynakları Araştırma Şube Müdürlüğü Yayın No:122.

Kaplan, M., T. Köseoğlu, T. Aksoy, N. Pilanalı ve M. Sarı. 1995. Batı Akdeniz bölgesinde serada yetiştirilen domates bitkisinin beslenme durumunun toprak ve yaprak analizleri ile belirlenmesi. Tübitak Projesi. Proje No: TOAG-987/DPT-3, Antalya, 72 s.

Kaplan, M., S. Sönmez ve S. Tokmak. 1999. Antalya-Kumluca yöresi kuyu sularının nitrat içerikleri. Turkish Journal of Agriculture and Forestry, 23: 309-313.

Kick, H., H. Bürger and K. Sommer. 1980. Gesamtgehalte an Pb, $\mathrm{Zn}, \mathrm{Sn}, \mathrm{As}, \mathrm{Cd}, \mathrm{Hg}, \mathrm{Cu}, \mathrm{Ni}, \mathrm{Cr}$ and $\mathrm{Co}$ in landwirtschaftlich und gartnerisch genutzten Boden Nordrhein-Westfalens. Landwirtsch Forschung, 33: 12 -22.

Kovancı, İ. 1985. Bitki Besleme ve Toprak Verimliliği Ders Notları. Ege Üniversitesi Ziraat Fakültesi Yayın No: 107/1, 244 s.

Lindsay W.L. and W.A. Norvell. 1978. Development of a DTPA soil test for zinc, iron, manganese and copper. Soil Science Society of America Journal, 42: 421-428.

Maltaş, Ş.A. ve M. Kaplan. 2015. Antalya (Merkez İlçe)'da yetiştirilen örtüaltı güzlük domates bitkilerinin (Solanum lycopersicum L.) beslenme durumlarının belirlenmesi. Akdeniz Üniversitesi Ziraat Fakültesi Dergisi, 28(1): 33-38.
Manga, İ., Z. Acar ve İ. Ayan. 1995. Baklagil Yem Bitkileri. Ondokuz Mayıs Üniversitesi, Ziraat Fakültesi Yayın No:7, 347 s.

Moltay, İ., S. Soyergin, N. Sürmeli, Ç. Genç ve M. Yürektürk. 1995. Doğu Marmara bölgesi örtüaltı yetiştiriciliğinde hıyarın beslenme durumunun belirlenmesi üzerine bir araştırma. T.C Tarım ve Köyişleri Bakanlı̆̆ı, Tarımsal Araştırmalar Genel Müdürlüğü, Bilimsel Araştırma ve İnceleme Yayın No: 52.

Motsara, M.R. and R.N. Roy. 2008. Guide to Laboratory Establishment for Plant Nutrient Analysis. FAO Fertilizer and Plant nutrition bulletin. Food and Agriculture Organization, Rome. p.219.

N'dayegamiye, A. and D. Cote. 1989. Effect of long-term pig slurry and solid cattle manure application on soil chemical and biological properties. Canadian Journal of Soil Science, 69(1): 39-47.

Nelson, D.W. and L.E. Sommer. 1982. Total Carbon, Organic Carbon and Organic Matter. In: Methods of Soil Analysis, Part 2: Chemical and Microbiological Properties. (Eds: A.L. Page, R.H. Miller, D.R. Keeney), American Society of Agronomy, Madison, WI, pp 539-579.

Olsen, S.R., C.V. Cole, F.S. Watanable and L.A. Dean. 1954 Estimation of available phosphorus in soils by extraction with sodium bicarbonate. U.S. Department of Agriculture, Circular 939. US Government Printing Office, Washington, DC.

Özkan, F.C. 2008. Antalya ve çevresi örtüaltı domates yetiştiriciliğinde toprak verimliliği, bitki besleme, bazı kalite ve stres parametreleri arasındaki ilişkiler. Ege Üniversitesi Fen Bilimleri Enstitüsü Doktora Tezi.

Pratt P.F. 1965. Potassium. In: Methods of Soil Analysis. 2nd ed (Ed: C. A. Black), ASA, Agronomic Monograph 9, Madison, WI, pp. 1023-1031.

Press, C.M., W.F. Mahaffee, J.H. Edwards and J.W. Klopper. 1996. Organic by-product effects on soil chemical properties and microbial communities. Compost Science and Utilization, 4(2): 70-80.

Richards, L.A. 1954. Diagnosis and Improvement of saline and alkali soils. Agriculture Handbook 60, USDA \& IBH Publishing Company Limited, New Delhi, India, pp. 98-99.

Schlichting, E. and H.P. Blume. 1966. Bodenkundliches Praktikum. Verlag Paul Paney, Hamburg und Berlin, pp. 121-125.

Scofield, C.S. 1935. Salinity of Irrigation Water. Smithsonian Institute, Annual Report, Washington D.C., pp. 275-287.

Shen, A., L. Xue Yuan, I. Kanamori and T. Arao. 1996. Effect of long term application of compost on some chemical properties of wheat rhizosfere and non-rhizosfere soils. Pedesphere, 6(4): 355-363.

Sillanpää, M. 1990. Micronutrient assessment at country level: An international study. FAO Soils Bulletin 63. Food and Agricultural Organization of the United Nations, Rome.

Sönmez, İ. ve M. Kaplan. 2007. Antalya-Demre yöresinde domates yetiştirilen sera topraklarının bazı verimlilik özelliklerinin değerlendirilmesi. Akdeniz Üniversitesi Ziraat Fakültesi Dergisi, 20(1): 29-35.

U.S. Salinity Laboratory, 1954. Diagnosis and Improvement of Saline and Alkali Soils, USDA Handbook 60. U.S. Government Printing Office, Washington, DC, USA, pp.1-160.

USDA, 1998. Keys to Soil Taxonomy. In: USDA Handbook, 8th ed Soil Survey Staff, Washington, DC.

USDA, 2002. Soil Electrical Conductivity Classification: A Basis For Site-Specific Management In Semiarid Cropping Systems. Agricultural Research Center, Lincoln. Nebraska. 